\title{
Judicial Cooperation and Legal Services between China and Vietnam
}

\author{
Yang qianqian \\ law school \\ Yunnan University of finance and economics \\ Kunming, China \\ Helenyang69@gmail.com
}

\begin{abstract}
China and South Asian countries are close neighbors connected by common mountains and rivers and are bonded by people-to-people and cultural ties. In the overall China-South Asia cooperation, the bilateral relationship between China and a single nation in this region is of great significance and China-Vietnam relationship is not an exception.
\end{abstract}

Key words-judicial cooperation; China-Vietnam; development

\section{INTRODUCTION}

Admittedly, South Asia has been more and more important to China and vice versa. The overall cooperation between China and South Asia has become a major theme for in-depth discussions, thus making contribution to strengthening the process of development between China and South Asian countries.

China and South Asian are close neighbors connected by common mountains and rivers and are bonded by people-topeople and cultural ties [1]. China and South Asia have experienced the ups and downs in the relationship both in the history and at present. But most importantly, China and South Asia still work closely to foster the traditional friendship, geographical proximity and economic complementarity, in a joint effort to build an Asian community of common interests and benefits.

In recent years, steady progress has been made in China's friendly relationship with South Asian countries. China has established partnership with most countries in the region and played a positive role in important regional affairs. China has committed its great support for South Asia's development. Series of projects have been carried out under the cooperation from Chinese side, thus contributing to the development of South Asian countries.

South Asian countries have opened up wider in such areas as trade and investment, finance and tourism, infrastructure and building to the outside world, including China. The first quarter of 2016, trade between China and South Asia reached USD 256 billion, up 15\% year-on-year. As South Asian markets are highly complementary and the development strategies well aligned, there is huge potential for mutually beneficial cooperation between the two sides.
From my own view, besides many good opportunities for wonderful China-South Asia cooperation and development, one of the biggest challenges for China's current South Asian policy is how to address doubts about the motivations for China's foreign policy in the region, in particular, the so-called "Chinese rise". China has repeatedly stated that it is keen on promotion peaceful development and cooperation toward winwin outcomes and cooperation with South Asia as well as other nations in the region, but in some Asian's sentiments, China's rising profile in South Asia is not completely benign and peaceful. I still have a strong belief that China will keep its firm stance of "what is said will surely be done concurrently".

In the overall China-South Asia cooperation, the bilateral relationship between China and a single nation in this region is of great significance and China -Vietnam relationship is not an exception.

In modern times, in the fight against foreign colonial rule, the two peoples support each other, work together, and forged a deep friendship. After the founding of the People's Republic of China, the two countries established diplomatic relations in January 18, 1950.

China-Vietnam economic relations have seen stable and rapid development in trade with double-digit growth rate in recent years. This is unsurprising as China has been Vietnam's biggest trading partner for the past 11 years.

Cross-border trade, which has been posing problems for the authorities for years due to the long border, is now gradually being put in order. In addition, official trading channels have been increasing, adding more kinds of goods that previously were only traded in small volumes. A more open payment mechanism at the branches of the two countries' banks in the border area has encouraged businesses to pay through banking services, thus reducing risks and disputes in cross-border trade.

Bilateral trade relations are also expanding in scale, with more Chinese businesses from inland and coastal provinces reaching out to Vietnam, and Vietnamese businesses looking beyond the border to China's coastal provinces and economic zones. The two side's businesses also shifted from trade to forming joint ventures to manufacture and sell products in the two countries' enterprises concerning policies, market information and trade opportunities, as well as a great number 
of product exhibitions held in the two countries, especially in common border provinces.

Both countries had earlier set a goal for 2015 bilateral trade volume at US $\$ 60$ billion, but they beat this in the first ten months of 2014 alone, where bilateral trade almost reached US $\$ 66$ billion. Vietnam has also surpassed Singapore to become China's second biggest trading partner in the ASEAN region [2].

\section{THE ACTUAL ANALYSIS}

\section{A. The establishment of the legal system of China-ASEAN}

In November 2002, China and ASEAN signed "China ASEAN comprehensive economic cooperation framework agreement, to determine the general objectives of bilateral cooperation and action criterion and areas of cooperation, and officially launched the China-ASEAN Free Trade Area construction process. The economic and trade relations between China and ASEAN have entered a new stage of development. In November 2004, China-ASEAN signed a free trade area "goods trade agreement" and "Dispute Settlement Mechanism Agreement", for the trade between China and ASEAN provides legal protection.

In recent years, the two sides have made continued progress in defense exchanges and cooperation, and conducted a variety of exchange programs within the framework of China-ASEAN bilateral cooperation, ASEAN Regional Forum (ARF), ASEAN Defense Ministers' Meeting Plus (ADMM-Plus) and ASEAN plus Three $(10+3)$. China supported the security policy dialogue under the ARF, and hosted the workshop on disaster relief by armed forces, the non-traditional security forum and other events within the 10+3 framework. In 2011, China and ASEAN held the first defense ministers meeting.

The Chinese Academy of Military Sciences sponsored two "China-ASEAN Senior Defense Scholars' Dialogue" in 2008 and 2009 on the topics of "military modernization and regional mutual trust" and "security situation in East Asia and ChinaASEAN defense cooperation." "China-ASEAN Defense and Security Dialogue," which was launched in 2010, provides an opportunity for in-depth discussions on regional defense and security issues between defense policy-makers and defense scholars from the two sides.

Since 1997, China and ASEAN have been holding biennial ministerial meetings on combating transnational crimes. The Memorandum of Understanding on Cooperation in Nontraditional Security Areas was signed in 2004 and renewed in 2010. The two sides have also carried out close cooperation in combating drug trafficking, illegal immigration, piracy, terrorism, arms smuggling, money laundering, international economic and internet crimes and other transnational crimes.

Since 2004, the Chinese Ministry of Public Security has staged over 60 training courses and workshops on antinarcotics law enforcement, criminological technique, maritime law enforcement, criminal case studies, exit-and-entry administration, internet crime investigation and other subjects, and invited over 1,500 law enforcement officers from ASEAN member countries to China. In particular, from 2006 to 2011, the Chinese Ministry of Public Security organized five training programs for ASEAN law enforcement liaison officers, during which 92 officers from ASEAN countries studied Chinese language and police knowledge in China.

China and ASEAN have extended mutual support, and partnered with each other in confronting a series of severe natural disasters and epidemics such as Indian Ocean tsunami, Myanmar cyclone, Wenchuan earthquake, SARS and avian flu.

\section{B. Legal environment of Vietnam on threshold of China-South Asia development}

The recent years marked an important turning point in the process of building and improving legal environment in Vietnam. The Vietnam Government has created and effectively improved a legal system that ensures national development within the framework of legality, ensures the proper development of social relations and formation of a stable legal order, contributing to creating a state governed by law as it is today.

Not only have laws on organization and operation of the state apparatus been improved, but those on business and trade, finance and credit, land and intellectual property, education and health and other social fields, as well as codes on administrative and judicial procedures, have also been passed to meet the requirements of diversified relations in a market economy which has become more deeply and comprehensively integrated in the global and regional economies.

The legal system has also become more democratic, humane, public and transparent. Laws have been passed with the primary and direct role of regulating social relations, thus ensuring democracy in proposing legislative initiatives and public participation in the lawmaking process. Publicity and transparency of the legal system have enabled people to access the law and legal services in a faster, simpler and cheaper manner. The Government has simplified administrative procedures, enacted more laws on judicial proceedings and assurance of social security, introduced better law enforcement mechanisms and reformed criminal policies towards reducing penalties.

The legal system has been made consistent with international and regional legal values. All new laws reflect the principle of respect for international commitments and agreements. On the other hand, international cooperation in the legislative process and absorption of human values in the lawmaking process on the basis of harmony between traditional and modern cultures have been constantly applied to the process of drafting and applying laws.

All this leads to laying a good foundation for both Vietnamese and Foreign citizens to do business and make investment in Vietnam. Most typically, according to the amended Housing Law which took effect on July1, 2015, Vietnam officially allowed foreign citizens to buy houses for the first time with a simple requirement as they have only 3month entry visa to Vietnam. The new law is extended the rules that before applied to apartments. This allowed the Foreigners own any property for a maximum of 50 years and 
enjoy the same rights to lease, transfer or sell the property as Vietnamese citizens.

\section{Judicial Relation between China and Vietnam}

China and Vietnam signed a memorandum of understanding on expanding judicial cooperation between their top courts in Beijing on March 25, 2016. The two countries' top courts have made high-profile visits, exchanged information, promoted communication and exchanges between their regional courts, and participated in international conferences together since they inked an MOU on judicial cooperation in Hanoi, capital of Vietnam on April 18, 2011. Both sides agreed that the MOU has led to significant achievements and hoped to further deepen the exchange and cooperation between their top courts. They decided to revise and supplement the MOU as well as prolong its validity to Dec 31,2016 , before they sign a new one. According to the revised MOU, the two top courts will strengthen cooperation on exchanges of visits and training of judges, as well as share experience and information on judicial reform. They will also promote cooperation in research of typical cases and enhance teamwork between China and courts in ASEAN countries. President of China's top court Zhou Qiang said China's Supreme People's Court cherished the friendship with the Vietnamese People's Supreme Court and hoped the two sides will boost China-Vietnam relations by deepening their communication and cooperation. According to this memorandum, the following four particulars have agreed.

1) The two parties agree to establish and keep a longterm friendly cooperative relationship and understanding of legal professionals of the two countries.

2) On a reciprocal basis, the two parties will exchange delegations to visit each other and the inviting party shall provide necessary assistance.

3) The two parties will conduct various kinds of exchange activities including study tours, training programs, seminars and joint research projects, etc.

4) The two parties will frequently exchange related information, materials and publications.

These processes have been showing the historical background judicial cooperation between China and Vietnam.

At present, the judges of Vietnam are attending and participating in the seminars and workshops which are held by China. Besides, Vietnam judges are now studying in China by Scholarship. Moreover, Vietnam judges are also taking some courses provided by China. These courses are training course of China-ASEAN legal training base, 2015 China-ASEAN law enforcement officer training course and China-ASEAN legal forum and one belt one road forum on rule of law [3].

\section{The criminal judicial assistance in the areas of China- Vietnam Problems and perfection}

Criminal judicial assistance is an important way of international society and countries in the field of judicial cooperation is between different countries and regions in the world based on the need to protect their own interests and the objective reality, for effective sanctions and curb the behavior of transnational crime, to overcome the limitations of criminal jurisdiction, according to the international treaties or bilateral reciprocal principle, each other on behalf of the prosecution Criminal judicial system of litigation. Criminal judicial assist helps to maintain the order of economic exchanges and cooperation, safeguard the interests of each other, prevention, warning of transnational crime, maintain national legal authority and the judicial justice; help to protect a country in foreign enterprises, citizen's life and property safety. It is helpful in rapid detection of transnational crime, thus contributing to the regional economic development.

China and Vietnam signed the "civil and criminal judicial assistance treaty" between countries. Yunnan border of the public security and the prosecution also signed a law enforcement cooperation documents with the corresponding agencies in Vietnam. China set up "to combat transnational crime of trafficking in women and children law enforcement cooperation Liaison Office" in Yunnan. The incidence of criminal cases involving the overall upward trend, there are some new crime. Transnational crime in Yunnan Province in the past multiple is drug-related crimes and the crime of abducting and trafficking people. Now there's a telecommunications fraud, involving incense smoke crimes, counterfeit money crimes such as economic crimes. In telecommunications fraud, a lot of suspects and criminals in foreign countries, while the victims in china [4]. Prosecutors investigating the duty crime of flight in recent years are basically flat. Transfer of Vietnam for suspects of Chinese nationality, the carrying out of the country money rarely handed over to China, sometimes by the payment related costs. Transferred to the multi contingent back, persuaded to return, extradition is few, this China and Vietnam no extradition treaty, extradition procedures complex. With the "going out" the implementation of the strategy, the Chinese employees abroad for crimes committed in the enterprise, and foreign relevant judicial authorities to suspect for Chinese nationality or business for Chinese enterprises grounds shall be under the jurisdiction of, which will bring prosecutor investigation crossborder investigation, forensics.

Central Political Bureau of the Communist Party of Vietnam Issue resolution $08-\mathrm{NQ} / \mathrm{TW}$, and put forward the reform requirement of strengthening the construction of judicial function in the coming period. The mission of the strategic plan is to improve Vietnam's justice system by promoting the core judiciary aims, namely the rule of law and regional peace and tranquility, enhancing reliability and public trust in the judicial system, adjudicating cases fairly and speedily in accordance with law and upgrading the integrity of the courts [5].

\section{CONCLUSION AND DISCUSSION}

\section{A. How to avoid legal disputes between China and South Asian in future?}

There must be proper legal corporation between China and South Asian countries harmonizing different application of legal issues in these jurisdictions. 
Force the governments in the region to introduce Common Directive relevant to finance, trade, trade cooperation, interconnection, non-traditional security, energy security like in EU.

\section{B. The idea of improving the legal system of China-ASEAN cooperation}

China-ASEAN legal cooperation center was registered as per the approval by the Chinese Ministry of Civil Affairs in the end of 2011, which is in charge of the China Law Society, and it is an unofficial social organization which bears the China ASEAN Inter-legal co-operation tasks. It's organized by the Chinese Law Academic Exchanges center, Beijing Dacheng Law Offices and Hainan Arbitration Commission.

The center aims to develop a platform that integrates legal resources of China and ASEAN countries. By promoting exchanges and cooperation between legal professionals, it will integrate legal, economic and social resources in China and ASEAN countries, with a view to improving the quality and efficiency of cross-border legal services within the ChinaASEAN Free Trade Area (CAFTA), and contributing to the development of CAFTA in such fields as trade, investment, tourism, education, culture, etc.

\section{1) To propel China-ASEAN legal co-operation.}

The center mission that promote legal service-related cooperation and co-ordination between China and ASEAN countries, and lay a solid legal-service foundation for the comprehensive development of China-ASEAN relations, by absorbing members, council-member organizations and cooperative organizations.

\section{2) To facilitate the integration of resources in China and} ASEAN.

The center mission that develop economic and trade ties between China and ASEAN countries, by establish closer contacts with legal and business communities of ASEAN countries, and thereby integrating relevant resources.

3) To promote the development of legal systems in China and ASEAN.

The center mission that contribute in the development of legal systems in China and ASEAN, by promoting professional and non-governmental legal study, and the exchanges and fusion of legal cultures of China and ASEAN countries.

4) To meet the needs of fast development of China and ASEAN.

5) To echo China's development strategy of opening up.

Globalization has made us increasingly interdependent with each other in recent years changing the dynamics of international relations. Problems, no matter where its origin is, cannot remain isolated today demanding collective actions for solutions. Nation States are interconnected with each other through a number of international treaties and agreements covering different areas of cooperation. The international network is so strong that the impact of globalization quickly spreads everywhere. Law, I believe, works as a common thread to bind all these together.
Law, indeed, is the solid foundation of governance and good governance is based on the rule of law. We therefore need to establish sound legal base for the effective implementation of our national policies and institutionalize strong cross-border legal mechanism for enhanced international cooperation. In this context, I hope, this Forum would be instrumental in bringing out innovative ideas with constructive deliberations and indepth discussions on various legal issues of common interest in the region.

We have seen that the objective of achieving economic integration in South Asia is taking a long time as the process is moving too slowly. The region is endowed with abundant natural resources and cultural heritage offering many more trade and investment opportunities. The potential areas of investment include hydropower, ago and forest based industries mining, and various manufacturing and service industries. As an observer in SAARC, China has opened up the opportunities of forging greater collaboration between China and the South Asian nations. We hope we should exploit such opportunities and exploit untapped potentials under China South Asia Cooperation for the larger development interest in the region.

It is pertinent here to underline that the one belt one road initiative put forward by President Xi Jinping of the People's Republic of China is of paramount importance for the development of the region. The framework holds great potentials to enhance regional connectivity, trade, tourism and other economic activities among the countries to be connected by it which would greatly contribute to better achieve regional harmony, peace and development. This great vision and hope she can be a gateway to South Asia in the southern silk route as a dynamic land bridge of multiple economic opportunities in the region.

\section{ACKNOWLEDGMENT}

This work was supported by the Science Foundation and Major Project of Educational Committee of Yunnan Province (No. 2016ZZX139); The National Science Education "in 13th Five-Year" 2016 year project planning of National Social Science Fund (No.CGA160207)

\section{REFERENCES}

[1] M.P. Baumgartner, "The moral order of a suburb," Oxford University Press, Oxford, 1988.

[2] H. Wei, "Study on Chinese ASEAN cooperation from the perspective of regionalism," Word knowledge press, Beijing, 2006.

[3] N. Nguyen. Dzung, "Vietnam Patent Law Substantive Law Provisions and Existing Uncertainties," Chicago-Kent Journal of Intellectual Property, 2015, pp. 138-156.

[4] Legislative Affairs Office of Yunnan provincial government, "Memoirs of a legal work in Yunnan," Yunnan people press, vol. 1, 2015, pp. 143143.

[5] Nader, and Laura, "Law in culture and society," University of California Press, Berkeley, 1997. 